\title{
Portraits of Puppet Art Thimplong at District Nganjuk: Reduction of Local Culture in the Acceleration of Nowadays Era
}

\author{
Latif Kusairi \\ Institut Agama Islam Negeri (IAIN) Surakarta \\ latifkusairi2018@gmail.com
}

Depy Tri Budi Siswanto

Universitas Islam Kadiri (UNISKA) Kediri Jawa Timur

depysiwanto@gmail.com

Submission Track:

Received: 31-08-2020

Final Revision: 31-12-2020

Available Online: $31-12-2020$

\begin{abstract}
This paper studies on how puppets as a media for preaching. One of them is puppet Thimplong brought by Eyang Sariguna. This puppet settings come from the Kingdoms of Kediri, Jenggala, Majapahit, Babad Tanah Jawi, and legends around Nganjuk. Currently, this puppet is rarely used and almost extinct. Therefore, the acceleration between this puppet and modern culture is needed for gaining acceptance among societies.
\end{abstract}

Keywords: Puppet Thimplong, preaching, extinction, preservation

\begin{abstract}
Abstrak
Tulisan ini melihat bagaimana wayang sebagai media dakwah. Salah satunya adalah Wayang Thimplong yang merupakan kesenian yang dibawa oleh Eyang Sariguna. Lakon Wayang Thimplong berlatarbelakang pada cerita Kerajaan Kediri, Jenggala, Majapahit, Babad Tanah Jawi dan legenda yang ada di sekitar wilayah Nganjuk. Saat ini wayang timplong jarang sekali digunakan dan nyaris punah. Oleh karena itu, perlu adanya akulturasi dengan budaya modern agar bisa diterima masyarakatnya.
\end{abstract}

Kata Kunci: Wayang Thimplong, dakwah, kepunahan, Pelestarian. 
Portraits of Puppet Art Thimplong at District Nganjuk:...( Latif Kusairi \& Depy Tri Budi Siswanto)

\section{INTRODUCTION}

District Nganjuk is one of districts in East Java Province. It has appeared since the early $10^{\text {th }}$ Century in the Anjuk Ladang Insription ${ }^{1}$. In $17^{\text {th }}$ Century, several areas in Nganjuk belongs to Mancanegara Wetan, under the hegemony of the Kingdom of Mataram². Meanwhile, during the colonial era $(1831 \mathrm{AD})^{3}$ until the Japanese invasion, Nganjuk was a district (afdeeling). The development of this city continues as time goes by.

As an area that has been around for a long time, Nganjuk has various arts as a form of indigenous local culture there. These arts include: Mung Dhe dance, Sandhur arts, Puppet Gedog, and Puppet Thimplong. Those arts were born and developed in Nganjuk until now. The uniqueness of wach arts become an identity for District Nganjuk. Whether we realize or whether it is explained, the regional identity forms national identity. Therefore, the original arts, and others regional arts, constitute a systemic arrangement shaping national culture, Indonesia.

The existence of several arts originated in Nganjuk (nowadays) experiences decadence. Puppet Thimplong in local folklore is an art brought by Eyang Sariguna, a Mataram soldier. This art existed in Nganjuk in the $18^{\text {th }} / 19^{\text {th }} \mathrm{AD}$ and had Eyang Sariguna as the first puppeteer ${ }^{4}$. Puppet Thimplong is based on the stdy of the Kingdoms of Kediri, Jenggala, Majapahit, Babad Tanah Jawi, and legends around Nganjuk ${ }^{5}$. The other uniqueness is that the puppets are made of the wood of Waru Tengis (a tree that only exist in Pace, Nganjuk) not a leather.

Puppet Art Thimplong requires special attention. This art is reduced by globalization as a acceleration of nowadays era which is destructive to local culture. This is reflected in the society ignorance of puppet Thimplong in Nganjuk ${ }^{6}$. This ignorance is a result of infrequently performance of puppet Thimplong. Currently, puppet Thimplong is only

\footnotetext{
${ }^{1}$ J. Brendes, Oud-Javaansch Oorkonden, Nagelaten Transcripties, VBG Deel LX, (Batavia: Albrech/ 'sHage: M. Nijhoff, 1913), p 89.

${ }^{2}$ Aminuddin Kasdi, Perkembangan Birokrasi Tradisional di Jawa pada Abad XIV-XVIII (Kajian pada Periode Akhir Mataram), (Surabaya: Unesa University Press, 2011), pp 46-48

${ }^{3}$ ANRI, Resolutie. Bijlage XXV. Perjanjian Sepreh, 3 Juli 1830. (w.g.) van Lawick van Pabst.

${ }^{4}$ Damari, Samsul Hadi, and Aries Trio Efendy, Kabupaten Pace Dalam Lintas Sejarah, (Nganjuk: Kantor Perpustakaan dan Arsip Kabuapten Nganjuk, 2014), p. 44.

${ }^{5}$ Harimintadji, Habib M., Santoso, Suranto, dan Suwarno, Nganjuk dan Sejarah, (Nganjuk: Yayasan Salepuk, 2003), hlm. 180.

${ }^{6}$ Interview with Bisri Mustofa (21), Ulfa Hidayati (21), Wiwik Supraptiwi (63), Darmaji (24), Valeria Lisa O. (16), Anita Rahayu (20), Agus Sutrisno (66), Juminten (56), Yellda A. (21), M. Grisa (23) and Lamijo (50), on 24 August - 5 November 2017. The respondents are local people of Nnganjuk with multi region, age, education and profession background.
} 
performed once a year, at Nyadranan ${ }^{7}$ in Kepanjen, Pace, Nganjuk. When this problem is not addressed properly, it impacts the existence of puppet Thimplong. It will disappear gradually. This fact is real, due to only an active puppeteer of puppet Thimplong in Nganjuk.

In addition, youth generations, who have watched puppet thimplong performance, are not excited since they do not understand the language used in the performance of puppet Thimplong (Javanes language: Kromo Inggil) ${ }^{8}$. The lack of Javanese Language mastery among youth generations in Nganjuk is another concern. The Javanese language is replaced by another language gradually. The moral and identity crisis must be dealt with immediately before the local language and culture completely assimilated by globalization. This shoul become a national concern, for puppet Thimplong continues to be preserved and developed.

The accentuation of puppet Thimplong is not only about its existence as a local culture, but also its value for national value. There are many moral values in puppet Thimplong. Each story on its performance gives moral message which is relevant towards todays' life. Puppet Thimplong retains Javanese language for delivering stories. This language rooted in Indonesian culture in plurality form. Furthermore, puppet Thimplong has a high social value in which people are mobilized, gathered and interacted in its performance.

Puppet Thimplong must be recognized as a culture born in Nganjuk, as an original culture of Indonesia, an as national culture affiliated with national personality. Puppet Thimplong is an art unifying the nation. The essence of its performance reflects Bhineka Tunggal Ika unifying the nation. Therefore, a solution (not a discourse) is needed for preserving puppet Thimplong as the original art of Indonesia.

\section{DISCUSSION}

Puppet is a product of human culture containing aesthetic art. Puppet serves as a performance and guidance for human life. Historically, there are various theories about the origin of puppet in the world ${ }^{9}$. First, Hasae states that puppet is originated in Java island. Second, according to N.J. Krom, puppet is originated in India brought along with Hinduism

\footnotetext{
${ }^{7}$ Nyadranan is a ceremony cleaning up the village. This ceremony is carried out holistically in villages in East Java and some parts of Central Java

${ }^{8}$ Interview with Vina Widyaningtyas (20), Arfi Prasongko (24), and M. Huda (17) on 24 August - 5 November 2017. The three of them had watched puppet Thimplong performance, but they did not understand the story. This is also the case happen on youth generation in Nganjuk.

9 Jamal Ghofir, "Nilai Dakwah dalam Kebudayaan Wayang: Pemaknaan Atas Cerita Dewa Ruci", J Dakwah 2003, 14(2): 235-261., p. 236.
} 
Portraits of Puppet Art Thimplong at District Nganjuk:...( Latif Kusairi \& Depy Tri Budi Siswanto)

to Indonesia. Third, there is a theory argues that puppet is originated in China ${ }^{10}$. Those multi-perspectives were debunked when UNESCO, on 7 November 2003, declared that puppet as a world cultural heritage from Indonesia ${ }^{11}$.

Indonesia has various types of puppet spread out in this country including: Shadow Puppet Purwo, Puppet Suluh, Puppet Palembang, Shadow Puppet Banjar, Puppet Beber, Puppet Thengul, Puppet Golek, Puppet Orang, Mask Puppet, Puppet Cina, Puppet Klitik, Puppet Suket, Puppet Gedog, dan Puppet Thimplong ${ }^{12}$. The last puppet, puppet Thimplong is discussed further in this study. This puppet still survives until now in Nganjuk.

\section{Getting to Know Puppet Thinplong}

Puppet Thimplong was first introduced by Eyang Sariguna, a soldier of the Islamic kingdom of Mataram in Pace, District Nganjuk. It is around $18^{\text {th }} / 19^{\text {th }} \mathrm{AD}$, correlated with the arrival of Eyang Sariguna ${ }^{13}$. Furthermore, there were found social activities even before in Pace, District Nganjuk. In 1677 AD, there were 1000 families as communals ${ }^{14}$. Therefore, Pace, as the area occupied by Eyang Sariguna in $18^{\text {th }} / 19^{\text {th }} \mathrm{AD}$, can be socio-historycally justified.

When the word puppet Thimplong is mentioned, it sounds unfamiliar. The exact reason of calling it as puppet Thimplong is still uncertain. However, there is a tendency that the term Thimplong refers to sound of bamboo xylophone used in Puppet Thimplong performance. In puppet Thimplong performance, the most dominant sound heard is plong...plong...plong.

While other puppets are generally made of weather, wayang Thimplong is made of wood from Waru Tengis trees. These trees are only found in Pace. This raises assumption of why Sariguna uses that wood as a main material for making puppet. The tradition of making puppet Thimplong using Waru Tengis is still maintained. It makes the puppet Thimplong more expensive than others.

\footnotetext{
10 Anjar Mukti Wibowo and Prisqa Putra Ardany, "Sejarah Kesenian Wayang Timplong Kabuapten Nganjuk, J Agastya 2015, 5 (2): 182-203, p.190

${ }^{11}$ Lidya Desriyanti, "Diplomasi Budaya Indonesia Melalui Wayang Kulit di Amerika”, JOM FISIP2017, 4 (2): 1-13., p. 2

${ }_{12}$ Kantor Perpustakaan dan Arsip Daerah Kabupaten Nganjuk, op, cit., 25.

${ }^{13}$ According to writer's interpretation, the existence of Eyang Sariguna was obtained through the family geneanology. This is because puppet Thimplong was preserved through lineage, or Sariguna's descendants who stil alive in Pace. Read Damari, Samsul Hadi, and Aries Trio Efendy, op, cit., pp. 43-49

${ }^{14}$ Manuskrip Instruksi Amangkurat II. on 2 December 1677., in Aminuddin Kasdi, Perlawanan Penguasa Madura atas Hegemoni Jawa: Relasi Pusat-Daerah pada Periode Akhir Mataram (1726-1745), (Yogyakarta: Jendela, 2003), p. 166.
} 
The development of puppet Thimplong is dealt with the puppeteer. The puppeteers were originally derived genealogically. Sariguna, the creator of puppet Thimplong had a brother named Kartodrono. Kartodrono had no children, while Kartoguno had two children named Jewul and Budholusuk. Jewul had a child named Tawar. Meanwhile, Budholusuk had 5 children named Panidi, Madinem, Par, Simpen, and Sinem. All of Budholusuk children did not become puppeteers. Therefore, the existence of puppet Thimplong was not continued by them. However, though Ki Tawar's also did not have successor of puppeteer, the puppet Thimplong was preserved by $\mathrm{Ki}$ Talam and $\mathrm{Ki}$ Suwoto. $\mathrm{Ki}$ Talam is the father of $\mathrm{Ki}$ Suyadi $^{15}$, the one and only active puppeteer of puppet Thimplong in Nganjuk.
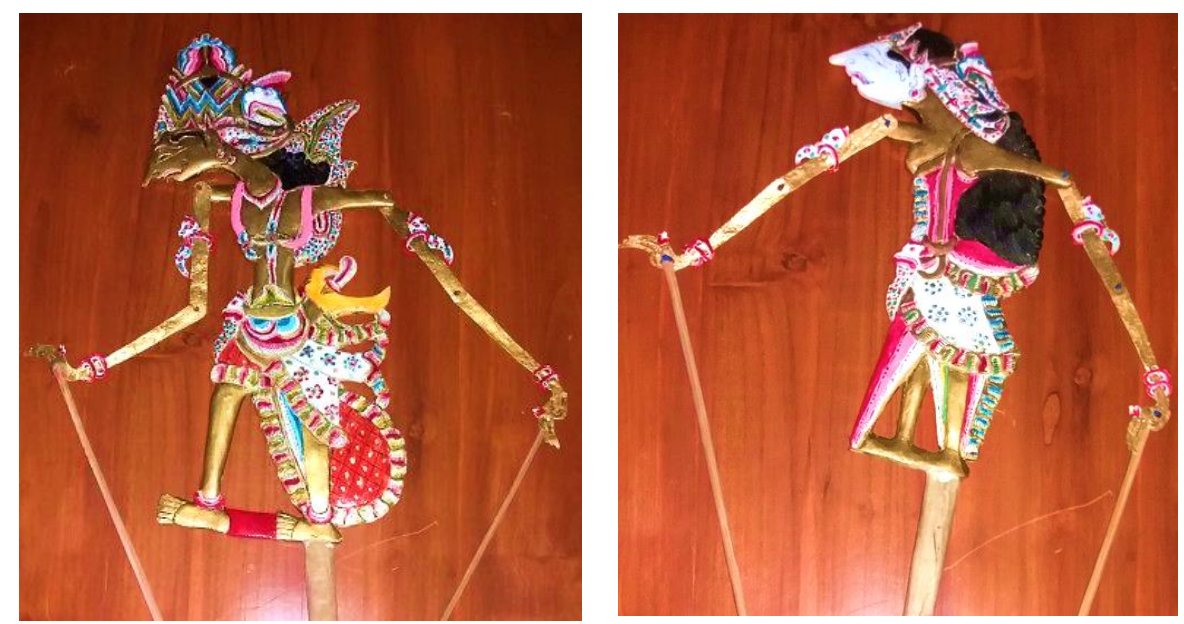

Picture 1 \& 2.

Picture of puppet Thimplong, lakon Queen and Princess Sekartaji ${ }^{16}$

Puppet Thimplong has 24 titles on its performance. The outlines are as follows: (1) the type of lakon kasepuhan performance, which tells on how someone seeks kaweruh and contains a lot of advice from a teacher or Begawan to her/his student; (2) the type of marriage performance, which tells about the ups and downs of finding a mate and living happily ever after being a husband and wife; (3) the type of birth performance, which tells of birth of an influential figure or a descendant of a king. Those stories were performed using approximately 100 puppet Thimplong ${ }^{17}$. The puppets are flexible in which the figures of kings, princesses, punakawan, and others can use the same puppets, though it has a different story.

\footnotetext{
${ }^{15}$ Kantor Perpustakaan dan Arsip Daerah Kabupaten Nganjuk, op, cit., hlm. 34.

${ }^{16}$ Writer's personal documentation on 24 August 2017. This property belongs to Suryadi, the one and only active puppeteer of puppet Thimplong.

${ }^{17}$ Harimintadji et.al, op, cit., p. 181.
} 
The instruments in puppet Thimplong is very simple consisting of only one gong, six kendang, and three gambang. Those are used for accompanying four characteristic features of puppet Thimplong including (1) Gendhing Awe-awe, which is used when performing a female golekan at the beginning of the performance; (2) Gendhing Grendel, which is used for accompanying jejeran (royal deliberations, giving an advice, or orders to royal courtiers); (3) Gendhing Ladrang, which is used for accompanying a war situation; (4) Gendhing Prahap / Closing, which is used for accompanying golekan dance as a sign of performance ending. The whole stories use Javanese language. This is a tradition carrying out since the puppet created.

\section{The Extinction of Puppet Thimplong}

The acceleration of nowadays era is an impact of science and technology. The impact is considered as a result for human live convenience. Life become increasingly hedonistic, practical, and individualist. On the one hand, technological advances become the foundation of modern life. On the other hand, it causes crisis of moral and identity on human being. Local culture seems to be replaced by gadgets, social media, or other virtual life. It is time for Indonesian people learning about "the ethics of remembering and the consequences of forgetting".

The reflection of acceleration is the diminishing prestige of local arts. Puppet Thimplong reached its peak in 1970. In 1970, puppet Thimplong was performed not only at Nyadranan events, but also at wedding party, khitanan, or thanksgiving in Nganjuk. Currently, it is only performed once a year at Nyadranan in Kepanjen village, Pace, Nganjuk.

When the puppeteer performs, only few people understand the story. This is because the audience do not master Javanese (Kromo Inggil) well. Many of them only participate in the puppet performance by holding their gadgets, taking pictures and uploading it on their social media, even without understanding what it is about ${ }^{18}$. In this case, Javanese do not take the blame, but the life of millennials is changing. According to writer's observation, nowadays, people in Nganjuk accustom their children to using Indonesian language, even some using foreign terms at home. This phenomenon happens for following the lifechanging. In fact, the regional language and the national language need to be balanced.

\footnotetext{
${ }^{18}$ Writer's observation
} 
While the regional language is a national identity, the national language is a unifying language.

This art performance, which is rarely performed, has another tough problem. Currently, there is only one puppeteer of puppet Thimplong named Suyadi. Suyadi is the son of Ki Talam, the previous puppeteer of puppet Thimplong. The main question is about how an art can be developed when only a puppeteer preserves it. This situation is very crucial, especially when the discussion come to the successor of puppet thimplong puppeteer.

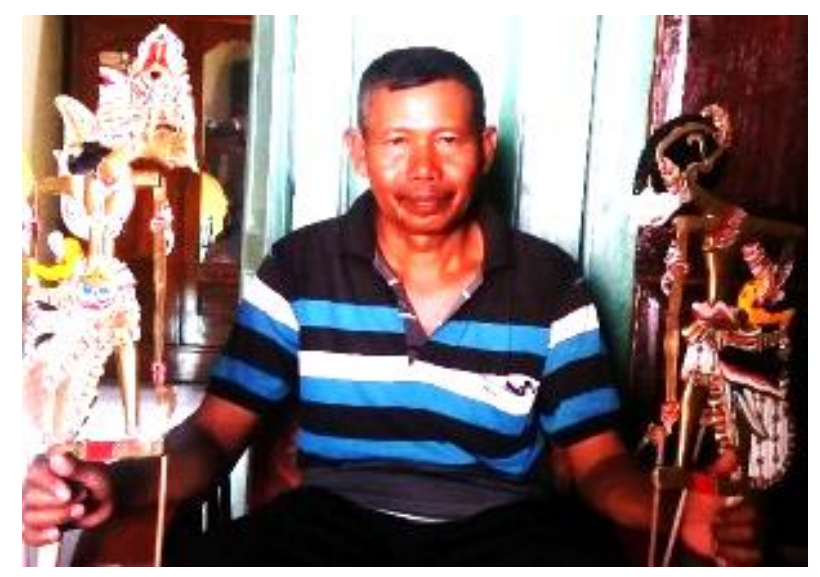

Picture 3.

Picture of Ki Suyadi, the last puppeteer of puppet Thimplong

The puppeteer is chosen hereditary, while Suyadi's descendants do not have the tendency to become puppeteer. His daughter is a teacher, and his son does not want to be a puppeteer ${ }^{19}$. The problem arises when Suyadi's retire from being a puppeteer. Moreover, the question happen whether puppet Thimplong become extinct. It is ironic when there will be the extinction of indigenous of Nganjuk local arts performance.

\section{The Preservation of Puppet Thimplong}

In order to preserve puppet Thimplong, the society only need to perform this performance as often as possible at folk events such as wedding party or khitanan. This also applies for others performance arts in Indonesia. The problem is that puppet thimplong is considered as a boring and an old-fashioned art that is delivered with Javanese language, a language that cannot be understood easily.

The society and the local government are the main components in preserving puppet Thimplong. Optimizing the role of local government is a main requirement at this time,

\footnotetext{
${ }^{19}$ Interview with Suyadi, the puppeteer of puppet Thimplong on 24 August 2017
} 
Portraits of Puppet Art Thimplong at District Nganjuk:...( Latif Kusairi \& Depy Tri Budi Siswanto)

considering that Suyadi did not receive any assistance from the local government due to the preservation of puppet Thimplong ${ }^{20}$. It is detrimental if the preservation is not carried out immediately, given the current situation of puppet Thimplong.

Local governments can insert puppet Thimplong as art performance in their government events. The more it is performed, the more puppet Thimpong is known by the society. They will be interested in performing this show. Furthermore, regular performances can strengthen the identity of Nganjuk.

The preservation can also be carried out by integrating local content subjects or cultural art with puppet Thimplong in secondary school. Puppet Thimplong contains local wisdom values. The stories relate to local story about the birth of several villages in Nganjuk, including Sinencongsari, Lahire Jaka Slawah, Jaka Ombak, Bedhae Tanjung Anom, Bujan Negara, and Kalimati. It can attract excitement from the students since it relates to the area where they live.

By preserving puppet Thimplong at schools, the problem of mastering Javanese language is also resolved. Javanese language become Javanese disparity. Indeed, in performing puppet Thimplong, the puppeteer uses high level of Javanese language (Kromo Inggil) which give another difficulty to youth to understand the story. The writer had a thought to suggest performing puppet thimpong using Indonesian language. It makes the performance easier to understand for youth. However, the commutation prolongs the disparity between the Javanese people with their language. The commutation will also reduce and destroy the essence of puppet Thimplong as a local culture. For this reason, it is more efficient to learn both puppet Thimplong and Javanese language at scholl. Javanese language is preserved along with puppet thimplong. Learning puppet Thimplong at school will be facilitated by teacher who waster Javanese language (Kromo Inggil) or Javanese language teacher. The students will be able to understand both puppet thimplong and Javanese language better.

In addition, it seems more effective when puppet thimplong is raised as extracurricular activities. The students will go deeper learning puppet thimplong as a cultural heritage. By raising it as extracurricular activities, puppet thimplong become familiar. When all secondary schools implement this idea, there will be no extinction of local arts in Nganjuk. The teachers' role must be more massive. It is not certain that they master and understand

\footnotetext{
${ }^{20}$ Interview with Suyadi, the puppeteer of puppet Thimplong on 24 August 2017
} 
the history of puppet Thimplong, the types of puppets, the instruments, the performance tools, and so on. The government need to educate the teachers first in Nganjuk about puppet Thimplong or other arts performance. MGMP, as a forum where the subject teachers are gathered, can be used as a media for training them. Therefore, the preservation runs well.

According to the writer, moreover, the puppeteer should be allowed outside of heredity. The hereditary selection makes these arts fade away. Basically, the more puppeteers can perform, the more opportunity of this puppet can be developed. The students who have been introduced to puppet Thimplong, is able to be puppeteer. This is a positive result of preserving puppet thimplong. In order to realize the efforts, there must be approaches to Suyadi as the descendants of the first puppeteer for achieving the proposal.

By having many puppeteers, it is expected that more performances performed. This can be developed further. Technological advances and globalization can be used for the development of puppet thimplong. Korean artists' live broadcasts on social media are very attractive to young people. Puppet thimplong could also be broadcasted live via social media or mobile applications on smartphones to attract young people. this is a new way to preserve local culture. Technological advances in the acceleration of today's progress can be used intelligently to preserve local culture in Indonesia.

Puppet thimplong is not only the heritage of Nganjuk community, but also the people of Indonesia. The preservation of local Nganjuk culture is a form of preservation of Indonesian culture. Puppet thimplong is a media that unites the nation, because it is a national art, born and developed in Indonesia. It is time for puppet thimplong to flourish, known not only by tha nganjuk community, but also by Indonesian people and the world. It needs attention, creative ideas, and efforts (which are not discourses) from all parties so that puppet thimplong and other arts in Indonesia continue to prosper and stay far from extinction.

\section{Conclusion}

Nganjuk has many local arts, one of which is puppet thimplong. The art was created by Sariguno, a Mataram solcier who lived in Pace, Nganjuk. This art is thought to have been born in $18^{\text {th }}$ century AD. The uniqueness of puppet thimplong is in the material. This puppet is made from Waru Tengis tree wood. Puppet thimplong has 24 stories, which are divided into three types, lakon kasepuhan, lakon perkawinan and lakon kelahiran. Some of the stories 
Portraits of Puppet Art Thimplong at District Nganjuk:...( Latif Kusairi \& Depy Tri Budi Siswanto)

in puppet thimplong performances include local stories of Nganjuk, such as Sinencongsari, Lahire Jaka Slewah, Jaka Ombak, Bedhae Tanjung Anom, Bujan Negara andKalimati.

Puppet thimplong is currently not recognized by the Nganjuk community itself. This art is only performed once a year in Pace District, Nganjuk Regency. This makes puppet thimplong less well known. the performance, which uses Javanese language (kromo inggit), does not seem to be understoof by young people in Ngnajuk Regency. Another problem is that there is only one puppeteer of puppet thimplong. The absemce of a successor from Suyadi's lineage (the current Thimplong puppeteer) makes this art even more concerning. A solution is desperately needed to overcome this problem, in order to preserve local Nganjuk arts.

Solutions and real efforts are needed to preserve puppet thimplong art. It is hoped that Nganjuk Regency Government can endeavor to preserve the puppet thimplong by carrying out regular performances. Puppet thimplong performance can be conducted by related agencies to coincide with major governmental event. With more frequent performances, the Nganjuk community will know more about this art. In addition, there must be aids and assistance in form of new equipments and innovations from local government to make puppet thimplong more attractive.

Another solution that can be applied is to integrate puppet thimplong art in schools, especially in cultural arts and local contents subjects. Alternatively, this art can be made an extracurricular activity. Teaching pupper thimplong early in schools makes it easier to understand Javanese as the language for puppet thimplong performances. In order to preserve puppet thimplong properly in schools, the Nganjuk local government can initiate education for teachers through teacher organization (MGMP). The last solution to preserve this art is to allow general public to become thimplong puppeteer. The more puppeteers there are, the more often this art will be performed. Hopefully, this art continues to flourish in the acceleration of Indonesia.

\section{Bibliography}

ANRI, Resolutie. Bijlage XXV. Perjanjian Sepreh, 3 Juli 1830. (w.g.) van Lawick van Pabst.

Brendes, J. (1913). Oud-Javaansch Oorkonden, Nagelaten Transcripties, VBG Deel LX, Batavia: Albrech/'s-Hage: M. Nijhoff.

Damari, Samsul H., and Aris T.E. (2014). Kabupaten Pace dalam Lintas Sejarah. Nganjuk: Kantor Perpustakaan dan Arsip Kabupaten Nganjuk. 
Desriyanti, L. (2017). "Diplomasi Budaya Indonesia Melalui Wayang Kulit di Amerika". JOM FISIP 4 (2): 1-13.

Ghofir, J. (2003). "Nilai Dakwah dalam Kebudayaan Wayang: Pemaknaan Atas Cerita Dewa Ruci”. J Dakwah 14 (2): 235-261.

Harimintadji, Habib M., Santoso, Suranto, and Suwarno. (2003). Nganjuk dan Sejarahnya (Henri Nurcahyo, Ed.). Nganjuk: Yayasan Salepuk.

Kantor Perpustakaan dan Arsip Daerah Kabupaten Nganjuk. (2015). Wayang Timplong dan Wayang Gedog. Nganjuk: Kantor Perpustakaan dan Arsip Daerah Kabupaten Nganjuk.

Kasdi, A.(2003). Perlawanan Penguasa Madura atas Hegemoni Jawa: Relasi Pusat-Daerah pada Periode Akhir Mataram (1726-1745). Yogyakarta: Jendela.

Kasdi, A. (2011). Perkembangan Birokrasi Tradisional di Jawa pada Abad XIV-XVIII (Kajian pada Periode Akhir Mataram). Surabaya: Unesa University Press.

Wibowo, Anjar Mukti and Prisqa Putra Ardany. (2015). "Sejarah Kesenian Wayang Timplong Kabuapten Nganjuk, J Agastya 5 (2): 182-203.

Interviews

\begin{tabular}{|c|c|c|c|}
\hline Name & Age & Occupation & Address \\
\hline Suyadi & 49 y.o & $\begin{array}{l}\text { The puppeteer of } \\
\text { puppet thimplong }\end{array}$ & $\begin{array}{l}\text { Ds. Kepanjen, Kec. Pace, } \\
\text { Kab. Nganjuk }\end{array}$ \\
\hline Agus Sutrisno & 66 y.o & Merchant & Ds. Jeruk, Kec. Baron, Kab. Nganjuk \\
\hline Anita Rahayu & 20 y.o & Student & $\begin{array}{l}\text { Ds. Mojokendil, Kec. Baron, } \\
\text { Kab. Nganjuk }\end{array}$ \\
\hline Arfi Prasongko & 24 y.o & Farmer & $\begin{array}{l}\text { Ds. Pacewetan, Kec. Pace, } \\
\text { Kab. Nganjuk }\end{array}$ \\
\hline Bisri Mustofa & 21 y.o & Student & $\begin{array}{l}\text { Ds. Watudandang Kec. Prambon, } \\
\text { Kab. Nganjuk }\end{array}$ \\
\hline Darmaji & 24 y.o & Farmer & $\begin{array}{l}\text { Ds. Sumbersono, Kec. Pramboon, } \\
\text { Kab. Nganjuk }\end{array}$ \\
\hline Juminten & 56 y.o & housewife & $\begin{array}{l}\text { Ds. Watudandang Kec. Prambon, } \\
\text { Kab. Nganjuk }\end{array}$ \\
\hline Lamijo & 50 y.o & $\begin{array}{l}\text { Elementary school } \\
\text { guard }\end{array}$ & Ds. Jetis, Kec. Pace, Kab. Nganjuk \\
\hline M. Grisa & 23 y.o & Student & $\begin{array}{l}\text { Ds. Lambang Kuning, Kec. } \\
\text { Kertosono, Kab. Nganjuk }\end{array}$ \\
\hline M. Huda & $17 \mathrm{y} . \mathrm{o}$ & $\begin{array}{l}\text { Senior high school } \\
\text { student }\end{array}$ & Ds. Pace, Kec. Pace, Kab. Nganjuk \\
\hline Sutoyo & 47 y.o & Farmer & $\begin{array}{l}\text { Ds. Pacewetan, Kec. Pace, } \\
\text { Kab. Nganjuk }\end{array}$ \\
\hline Ulfa Hidayanti & 21 y.o & Student & $\begin{array}{l}\text { Ds. Gebangkerep, Kec. Baron, } \\
\text { Kab. Nganjuk }\end{array}$ \\
\hline Varelia Lisa $\mathrm{O}$. & 16 y.o & $\begin{array}{l}\text { Senior high school } \\
\text { student }\end{array}$ & $\begin{array}{l}\text { Ds. Kepel, Kec. Ngetos, } \\
\text { Kab. Nganjuk }\end{array}$ \\
\hline Vina $\mathrm{W}$. & 20 y.o & Student & $\begin{array}{l}\text { Ds. Ngujung, Kec. Gondang, } \\
\text { Kab. Nganjuk }\end{array}$ \\
\hline
\end{tabular}


Portraits of Puppet Art Thimplong at District Nganjuk:...( Latif Kusairi \& Depy Tri Budi Siswanto)

\begin{tabular}{|l|l|l|l|}
\hline Wiwiek S. & 63 y.o & Pensioner & $\begin{array}{l}\text { Ds. Banjardowo, Kec. Lengkong, } \\
\text { Kab. Nganjuk }\end{array}$ \\
\hline Yellda A. & 21 y.o & Student & Kec. Bagor, Kab. Nganjuk \\
\hline
\end{tabular}

